\title{
AUTHORS' RESPONSE (DECEMBER7, 2017) TO THE LETTER TO THE EDITOR CONCERNING THE PAPER “TRENDS IN SMOKING AMONG SECONDARY SCHOOL AND HIGH SCHOOL STUDENTS IN POLAND, 2009 AND 2011"
}

Dear Editor,

We have read the letter from Dr. T. Kawada [1] regarding our published paper on „Trends in smoking among secondary school and high school students in Poland, 2009 and 2011" [2] with great interest. In response we would like to point out that our findings were mainly on tobacco smoking rates in the case of secondary and high school pupils as well as the trends observed during these times, and causes of smoking were not analyzed in our survey. Our questionnaire was based on the USA model used for monitoring studies, i.e., the Youth Risk Behavior Surveillance System (YBRFSS) [3], which enabled the defined relationships to be analyzed as described in the letter to the editor. Our studies were focused on the antihealth behavior that included tobacco smoking among adolescents of reproductive age and pregnant women, along with the health effects on their offspring. Many of our past publications are devoted to these topics [4-9].

The health behavior of adolescents is being constantly monitored, which is why another randomized survey was performed on over 15000 adolescents and 3000 pregnant women in 2017, using the same methodology as in the case of the 2009 and 2011 studies. We are in the process of analyzing the data and preparing a report of our findings. Many thanks for valuable comments, and as the letter to the editor by Dr. T. Kawada has suggested, we will soon present the comparison of the differences in the rates for adolescent tobacco smoking and nicotine addiction over the years 2009-2017 and related causes.

Key words:

Health education, Cigarette smoking, Tobacco epidemiology,

Smoking initiation, Secondary school students, High school students

\section{REFERENCES}

1. Kawada T. Letter to the Editor (June 10, 2017) concerning the paper "Trends in smoking among secondary school and high school students in Poland, 2009 and 2011”. Int J Occup Med Environ Health. 2018;31(4):537-9, https://doi.org/ 10.13075/ijomeh.1896.01226.

2. Wojtyła-Buciora P, Stawińska-Witoszyńska B, ŻukiewiczSobczak W, Wojtyła C, Biliński P, Urbaniak M, et al. Trends in smoking among secondary school and high school students in Poland, 2009 and 2011. Int J Occup Med Environ Health. 2017;30(5):763-73, https://doi.org/10.13075/ijomeh.1896.00741.

3. Center for Disease Control and Prevention [Internet]. Atlanta: The Center; 2017 (cited 2017 Dec 5). YRBSS questionnaire. 
Available from: https:/www.cdc.gov/healthyyouth/data/yrbs/ questionnaires.htm.

4. Wojtyła-Buciora P, Wojtyła C, Urbaniak M, Biliński P, KapkaSkrzypczak L, Wojtyła A, et al. Alcohol consumption in Polish middle and high school pupils - Has this rapidly increased during 2009-11? Ann Agric Environ Med. 2014;21(3):552-6, https://doi.org/10.5604/12321966.1120600.

5. Wojtyła-Buciora P, Klimberg A, Diatczyk J, Kapka-Skrzypczak L, Urbaniak M, Ulatowska-Szostak E, et al. Monitoring risk behaviour in adolescent pupils regarding consumption of psychoactive substances. Ann Agric Environ Med. 2017 Jun 6;24(2):350-5, https://doi.org/10.26444/ aaem/74449.

6. Wojtyła C, Wojtyła A. Alcohol consumption by pregnant women in Poland. J Health Inequal. 2017;3(1):51-7, https:// doi.org/10.5114/jhi.2017.69166.

7. Wojtyła C, Wojtyła-Buciora P. Cigarette smoking among pregnant women in Poland. J Health Inequal. 2017;3(1):47-50, https://doi.org/10.5114/jhi.2017.69165.

8. Bilinski P, Wojtyla A, Holownia P, Brzozka K, Boyle P. Epidemiological investigation to define the awareness of women on the hazards of smoking and drinking alcohol before and during pregnancy in Poland. Eur J Public Health. 2010;20 Suppl 1:S152.

9. Bilinski P, Wojtyla A, Holownia P, Zatonski W, Boyle P. Smoking during pregnancy-which behaviour has the highest risk? Eur J Public Health. 2010;20 Suppl 1:S285.

\section{Paulina Wojtyła-Buciora ${ }^{1,2}$, Barbara Stawińska-Witoszyńska} Wiola Żukiewicz-Sobczak ${ }^{4}$, Cezary Wojtyła ${ }^{5}$, Piotr Biliński ${ }^{6}$, Monika Urbaniak ${ }^{7}$, Andrzej Wojtyła ${ }^{2}$, Jerzy T. Marcinkowski ${ }^{8}$, and Małgorzata Wojciechowska ${ }^{9}$

${ }^{1}$ Poznan University of Medical Sciences, Poznań, Poland Department of Physiology

${ }^{2}$ State Higher Vocational School in Kalisz, Kalisz, Poland Faculty of Medicine

${ }^{3}$ Poznan University of Medical Sciences, Poznań, Poland Chair of Social Medicine, Department of Epidemiology

${ }^{4}$ Pope John Paul II State School of Higher Education in Biała Podlaska, Biała Podlaska, Poland Department of Public Health

${ }^{5}$ Centre of Postgraduate Medical Education, Warszawa, Poland I Department of Obstetrics and Gynecology

${ }^{6}$ Institute of Psychiatry and Neurology in Warsaw, Warszawa, Poland III Psychiatric Clinic

${ }^{7}$ Poznan University of Medical Sciences, Poznań, Poland

Chair and Department of Facility Management Organizations in Health Care

${ }^{8}$ Poznan University of Medical Sciences, Poznań, Poland Chair of Social Medicine, Department of Hygiene

${ }^{9}$ Poznan University of Medical Sciences, Poznań, Poland Department of Mother and Child Health

Corresponding author: Paulina Wojtyła-Buciora Poznan University of Medical Sciences Department of Physiology Święcickiego 6, 67-781 Poznań, Poland (e-mail: paulinawojtyla@gmail.com)

This work is available in Open Access model and licensed under a Creative Commons Attribution-NonCommercial 3.0 Poland License - http://creativecommons.org/ licenses/by-nc/3.0/pl/deed.en. 